Association for Information Systems AIS Electronic Library (AISeL)

PACIS 2005 Proceedings

Pacific Asia Conference on Information Systems

(PACIS)

December 2005

\title{
The Impact of Perceived Risk on the Capital Market's Reaction on Outsourcing Announcements
}

\author{
Heiko Gewald \\ Johann Wolfgang Goethe-University \\ Tom Gellrich \\ Johann Wolfgang Goethe-University
}

Follow this and additional works at: http://aisel.aisnet.org/pacis2005

\section{Recommended Citation}

Gewald, Heiko and Gellrich, Tom, "The Impact of Perceived Risk on the Capital Market's Reaction on Outsourcing Announcements" (2005). PACIS 2005 Proceedings. 69.

http://aisel.aisnet.org/pacis2005/69

This material is brought to you by the Pacific Asia Conference on Information Systems (PACIS) at AIS Electronic Library (AISeL). It has been accepted for inclusion in PACIS 2005 Proceedings by an authorized administrator of AIS Electronic Library (AISeL). For more information, please contact elibrary@aisnet.org. 


\title{
The Impact of Perceived Risk on the Capital Market's Reaction on Outsourcing Announcements
}

\author{
Heiko Gewald \\ Johann Wolfgang Goethe-University \\ E-Finance Lab \\ Mertonstraße 17, 60054 Frankfurt, Germany \\ gewald@wiwi.uni-frankfurt.de
}

\author{
Tom Gellrich \\ Johann Wolfgang Goethe-University \\ E-Finance Lab \\ Mertonstraße 17, 60054 Frankfurt, Germany \\ gellrich@wiwi.uni-frankfurt.de
}

\begin{abstract}
Outsourcing has become a widely accepted option in strategic management which, as every business venture, bears chances and risks. Supplementing the popular area of research on the merits of outsourcing, this paper examines how stockholders rate the corporate sourcing decision with regard to the perceived risk they associate with this transaction. Using event study methodology and multivariate cross-sectional OLS-regression, we analyze a sample of 182 outsourcing transactions of the global financial services industry between 1998 and 2004 in order to investigate the risk-specific drivers of excess returns to shareholders. The analysis studies the impact of risk-specific independent variables which include the transaction size, length, outsourced business functionality, and experience with outsourcing. Our findings indicate that risk-mitigating strategies have significant explanatory power, indicating that capital market's reaction to an outsourcing announcement might at least partly be forecasted. Results show a positive correlation of market reaction and business process outsourcing of financial services companies. We also find strong evidence indicating that capital markets react positively towards relative large transactions compared to the market capitalization of the outsourcing firm. For service providers our results show that traditional IT-related sourcing projects or insourcing of administrative processes has a significant positive correlation with market reaction.
\end{abstract}

Keywords: Outsourcing, Perceived Risk, Global Financial Services Industry, Capital Market

\section{Sourcing, Risk and the Capital Market}

The examination of the outsourcing phenomenon, the process when a service provider takes ownership of corporate resources and manages those resources on behalf of the outsourcer (Kern, et al. 2002), has been a domain of the IS community for several years now. In recent times the questions "why to outsource" and "what to outsource" have been succeeded by the question "how to outsource", i.e. how to make best use of the opportunities enabled by the ability to use resources from outside the own company.

An integral part of the "how"-question is an assessment of the risks associated with conducting outsourcing. Multiple papers have been written on this issue examining it from several different perspectives. We aim to enhance the knowledge on risk in outsourcing by including the view of a neutral referee, the capital market in our analysis. If publicly listed companies announce outsourcing deals, the capital markets react to this announcement. The reaction can either be positive or negative, depending on the level of inherent risk perceived by the investors. The level of risk associated with the deal depends on the impact on the 
business model of the outsourcing company and the bottom line benefits resulting from the deal, bearing in mind that outsourcing contains both, risks and chances.

Contemporary research on risk in outsourcing has focused on empirical ex-post studies, analyzing outsourcing engagement and deriving the failures that occurred (Gewald and Hinz 2004). It is an expectation of shareholders, that senior management is aware of those risks and deploys risk mitigating strategies when entering an outsourcing project. We assume that the stock market's reaction to the announcement of an outsourcing deal depends to a large extent on the level of risk investors perceive is associated with the project. Up to now, little attention has been devoted to the risk specific factors that influence investors' reaction to the announcement of an outsourcing transaction. It is still not thoroughly analyzed how capital markets react on sourcing announcements of companies, especially of highly integrated financial services institutions. It is of high interest to find out how capital markets react to specific sourcing risks and which common deal characteristics are positively (or negatively) rewarded by capital markets. The capital market's reaction to the perceived risk of an outsourcing engagement is difficult to frame theoretically. As the reaction of the market as a whole depends on the collective decisions of all individual investors, we chose to employ Perceived Risk Theory (PRT) as theoretical foundation.

The objective of this paper is to understand risk-specific factors that affect abnormal stock returns around sourcing announcements of the financial services industry. It is of special importance to gather those insights, as the changing role of the $\mathrm{CIO}$, from delivering bites and bytes to delivering business value, also includes a more exposed position to corporate shareholders. Thus gaining knowledge on how the capital markets react towards certain deal characteristics helps to customize the outsourcing transaction to the specific intentions of the corporation.

No other study we are currently aware of provides an in-depth analysis of the factors that influence the value creation process in the global financial services industry. We chose that sector for two reasons: (1) This industry is the second largest buyer of outsourcing services, just after public bodies (Caldwell 2003; TPI 2005). (2) The financial services industry has an immediate focus on risk, as several national and international regulatory bodies have issued legislations that enforce banks to re-think their risk management and incorporate operational risk, the risk of losses resulting from inadequate or failed internal processes, people and systems or from external events (BIS 2004). This type of risk also applies to outsourcing.

This paper is structured as follows: We provide an overview on the current state of research regarding the risks of outsourcing, PRT in IS research and event studies on outsourcing. Thereafter we developed hypotheses grounded on theoretical considerations and provide information on the methodology of our study. Finally we display the results and close the paper with a discussion and conclusion.

\section{Current State of Research}

\subsection{IS Research on Risk in Outsourcing}

IS research has adopted the outsourcing phenomenon as an area of research interest since the last decade of the foregone century and its attractiveness to the IS community remains unbroken (Dibbern, et al. 2004). Outsourcing research traditionally addresses three major questions: (1) why a corporation should employ outsourcing as a strategic tool, (2) what to outsource and (3) how outsourcing should be conducted (e.g. contractual or relationship matters). The most current area of interest is the discussion of possible implications of outsourcing. Authors are increasingly investigating also the undesirable outcomes of outsourcing and assess ways to avoid them. An early assessment of the risk of outsourcing has been conducted by (Earl 1996), further active contributor to the discussion on this field 
are (Aubert, et al. 1998; Currie 1998; Willcocks, et al. 1999) to name only a few. A review of the literature conducted by (Gewald and Hinz 2004) gives a broad overview on the topic and lists the most often quoted risks.

\subsection{IS Research on Perceived Risk}

Perceived risk is a construct that builds on the beliefs of uncertainty regarding possible negative consequences. In marketing research perceived risk has been studied as it affects consumer purchase behavior because of uncertainty about a product or service resulting from imperfect information (Bauer 1967). The expectation of losses associated with a purchase acts as an inhibitor to buying behavior (Peter and Ryan 1976). In IS research PRT has commonly been applied. For example to analyze IT-system adoption (Featherman and Wells 2004), the usage of web contents (Pavlou 2003) or the adoption of outsourcing (Benamati and Rajkumar 2003).

Perceived risk has been described as comprising the subjective perception of two components: the amount at stake and the degree of certainty about possible negative consequences (Cox 1967; Cunningham 1967). It is formally defined as "a combination of uncertainty plus seriousness of outcome involved" (Bauer 1967, p.25). Perceived risk therefore includes both measures: Subjective probability of loss and severity of the negative impact. If perceived risk exceeds the tolerable degree of the individual or organization, then this triggers the motivation for risk-reducing behavior (Cox 1967). In the case of this research this would mean that investors sell the respective stock of the outsourcer and/or the insourcer. Cunningham originally segregated perceived risk into six dimensions (Cunningham 1967): Performance risk, financial risk, opportunity/time risk, safety risk, social risk, and psychological risk. For IS research, Featherman and Pavlou suggest to replace safety risk, the risk facet gauging possible harm of physical damage to the human being, by privacy risk, the risk of loss of private information (Featherman and Pavlou 2003). The risk facets "psychological risk" and "social risk" (in depth discussed in (Mitchell 1992)) have been combined to form a single facet called "psychosocial risk" (which is in line with the research results of Featherman and Pavlou). This step has been taken to reflect the specific nature of this research and especially the research object. The psychosocial risk facet will construct the reputation risk inherent in the outsourcing decision, putting the reputation of the bank within the financial community at danger if it can not deliver its services. Time risk, the risk that the client loses time due to a lengthy vendor selection process if finally not deciding to outsource, has been taken out, as the study only includes outsourcing contracts which have been announced publicly as being closed. Therefore outsourcing projects which do not get to this stadium are excluded which implies the absence of time risk.

Based on these arguments the perceived risk of outsourcing is theorized to consist of the facets depicted in Table 1.

\begin{tabular}{|l|l|l|}
\hline Risk Facet & Description & Proxy in this study \\
\hline Performance risk & $\begin{array}{l}\text { The possibility of the outsourcing engagement not to deliver } \\
\text { the expected quality of service. }\end{array}$ & Complexity of contract \\
\hline Financial risk & $\begin{array}{l}\text { The possibility to pay more money to reach the expected } \\
\text { level of service than initially anticipated. }\end{array}$ & $\begin{array}{l}\text { Size of contract } \\
\text { Duration of contract }\end{array}$ \\
\hline Psychosocial risk & $\begin{array}{l}\text { The possibility that the reputation of the bank in its peer } \\
\text { group is harmed due to the decision to outsource services. }\end{array}$ & $\begin{array}{l}\text { Experience of service provider } \\
\text { Financial reliability of service } \\
\text { provider }\end{array}$ \\
\hline Privacy risk & $\begin{array}{l}\text { The possibility that sensitive client / internal data will be } \\
\text { misused by the vendor or that third parties gain unauthorized }\end{array}$ & Transaction focus \\
\hline
\end{tabular}


access.

Table 1: Description of risk facets and applicable proxies

Benatami and Rajkumar conducted the only quantitative study on perceived risk in outsourcing, we are aware of. They did a survey of 3,000 IT decision makers testing the influence of external environment, prior outsourcing relationship and perceived risk on the intention to use outsourcing of the application development function (Benamati and Rajkumar 2003). They found evidence for the role of perceived risk and concluded that more research is necessary to understand the perceived risk associated with outsourcing engagements.

\subsection{Capital Market Reactions on Outsourcing Decisions}

Several empirical studies on capital market reactions to outsourcing engagements have been conducted. In the following we summarized the most relevant to our paper in brief. (Hunton, et al. 2000) analyzed a sample of 77 information systems IS outsourcing announcements between 1990 and 1997. They found evidence that capital markets react positively on the announcements and abnormal returns were greater for smaller firms than for larger firms (defined by the market value). (Glassman 2000) examined 27 companies which undertook large information technology outsourcing initiatives between 1993 and 1999. Focus of this study was on IT mega deals. The author found an average gain in shareholder value of 5.7 per cent over the general market trend from two months prior to two months after the announcement (abnormal return). Glassman concluded that outsourcing creates value to shareholders as outsourcing has become a management technique that can reduce risk and increase flexibility by making costs variable. (Farag and Krishnan 2003) examined information technology outsourcing deal announcements between January 1994 and August 2001. They concluded that capital markets react positively to IT outsourcing announcements of IT industry firms and service industry firms. They find positive market reactions to strategic sourcing projects, but not for cost-cutting projects. (Oh and Gallivan 2004) analyzed a sample of 97 information technology outsourcing deal announcements between 1998 and 2001. Contrasting prior research, they find only weak evidence with regard to investors' positive reaction to IT outsourcing announcements. Specifically, they detect that abnormal returns are negatively associated with asset specificity and with contract size. They found no evidence regarding a significant association of abnormal returns and contract duration or between abnormal returns and cost-reducing IT outsourcing announcements. Thus, we can conclude that evidence regarding the capital market reaction of souring transactions is mixed and ambiguous; prior literature does not provide a valid link between perceived risks and investor behavior. The next part of the paper builds on PRT by deriving hypotheses.

\section{Hypotheses}

Our research approach reflects the risk facets of PRT and conjoins them with the risk of outsourcing as identified in current literature. We assume that stockholders assess an outsourcing engagement on the basis of risk and reward, thus valuing the level of risk subjectively associated with the transaction. Higher risk levels can be associated with potential divestments while a lower level might lead to an increasing investment in the company. Based on these assumptions, we propose the following hypotheses.

Size of contract: The monetary size of the contract is expected to play a significant role in determining the financial risk of the engagement. As contract volume increases, the contract itself becomes more complex, offering greater possibilities for misunderstandings between 
the parties which could result in (costly) renegotiations leading to non-anticipated costs burdens Furthermore monitoring costs and contract volume are positively correlated (Jensen and Meckling 1976), where the monitoring costs are difficult to anticipate ex ante. We measure the deal size by total contract value (TCV), the total amount of money to be paid over the agreed service period.

Hypothesis 1: Due to higher perceived risk of financial miscalculations and general financial risks of large projects, investors are expected to react negatively towards larger sourcing announcements.

Duration of Contract: The duration of the contract plays a significant role in many types of outsourcing arrangements (Oh and Gallivan 2004). Companies engaging into long-term contractual arrangements face increased risks as they lose flexibility to react on future developments (Lacity 2002; Willcocks, et al. 1999; Young and Hood 2003). A worst case scenario locks the client (in the context of this study we use the term "outsourcer" or "client" for the financial services company that contracts out parts of its formerly internal functions, and the term "insourcer", "vendor" or "service provider" for the company which takes over the service) in to a poorly-performing vendor, constraining the client's flexibility (Oh and Gallivan 2004). These findings lead to the assumption, that long running contracts inherent a higher level of perceived financial risk, as possible negative turn outs in the future are costly to be corrected. Duration of contract is measured in years.

Hypothesis 2: We expect investors to react negatively towards outsourcing contracts having a long duration.

Contract complexity: Formally, many outsourcing arrangements implied total outsourcing to a single vendor (Huber 1993; Venkatraman and Loh 1994), while nowadays multi-vendordeals receive wider attention (Currie 1998; Gallivan and Oh 1999). This can be attributed to greater propensity of firms to engage in selective or "smart" sourcing (Earl 1996; Lacity, et al. 1996) or functional outsourcing (Grover, et al. 1996). As on one hand, the outsourcer might benefit from advantages like increased negotiation power, on the other hand balancing out for the downsides is needed. Therefore we assume that the perceived performance risk is higher in multi-vendor surroundings, as those are more difficult to manage for the outsourcer. In order to measure the impact of the various deal constellations, we differentiate between simplistic one-to-one relationships and multi-vendor arrangements. We measure this deal characteristic with a binary variable: " 0 " for a single vendor and "1" for deals employing more than one vendor.

Hypothesis 3: Multiple service providers increase complexity, thus the risk not to deliver the required performance. Therefore we expect capital markets to react negatively towards deals including multi-vendor relationships.

Experience of the service provider: Business experience is a relevant factor in leveraging economies of scale (Bain 1954). An experienced insourcer that has performed a multitude of deals is in a better position to leverage synergies and to benefit from economies of scale and scope. Furthermore experienced vendors are assumed to have built in-house learning experience on avoiding the pitfalls of outsourcing projects (Lassig, et al. 2003; Willcocks, et al. 1999). Also the risk that arises from a vendor pretending to have capabilities that in reality are not present is mitigated as this behavior would probably have been noticed before in the market reducing the number of deals closed (Willcocks, et al. 1999). We therefore expect that investors value the experience of the insourcer through lower perceived psychosocial risk. Experience of the service provider is measured by the cumulated number of previously acquired deals.

Hypothesis 4: Experienced service providers have a higher reputation in the market, therefore investors react positively towards deal announcements including experienced vendors. 
Transaction focus: Outsourcing is also a strategic option for companies to concentrate on their core competencies (Prahalad and Hamel 1990; Quinn and Hilmer 1994). As the production of IT related task is usually not regarded being a core competence within the financial services sector, the outsourcing of business process comes much closer to it. Specific about business process outsourcing (BPO) is that the outsourcer needs to transmit non-encrypted data to the insourcer in order to process it. This implies a lot of trust regarding the fact that the insourcer could be a competitor in the market and use sensible client data to gain a competitive advantage. A typical process would be securities settlement which makes it necessary to transmit sensible client data like security orders and portfolio positions. Privacy risk a very sensible topic in BPO engagements (Gewald and Franke 2005).

We clustered business functionalities in four functional types in order to differentiate between core and non-core activities: IT-infrastructure outsourcing (ITI), application development and maintenance outsourcing (ADM), administrative processes outsourcing (APO) and, finally, BPO. Outsourcing of ITI and ADM functions can be stated as "non-core", while "typical" core financial processes are covered in APO and BPO (Friedrich and Gellrich 2003). For service providers traditional IT-related processes are scalable, flexible, homogeneous and usually standardized. Generally this leads to less complex integration projects associated with lower levels of risk.

Hypothesis 5: We expect sourcing of activities such as ITI and ADM to be rewarded by capital markets while outsourcing announcements with a high degree of perceived privacy risk (such as APO or BPO) will not be approved by capital markets.

Financial reliability of the service provider: A financially reliable vendor reduces the level of risk as the probability for a default and therefore the threat to the client of not being able to produce its own services is reduced (Lassig, et al. 2003; Michell and Fitzgerald 1997). Furthermore a financially stable vendor is generally more likely to be a reliable partner for the future of the engagement which reduces the risk of dependence on the service provider. These arguments sum up to the perceived level of psychosocial risk, as the default of the vendor would severely harm the reputation of the client in the market, due to its inability to deliver its service. As indicator for financial reliability we used the Return-on-Equity (RoE) of the service provider. A high RoE indicates that a company operates efficiently and profitable with its equity.

Hypothesis 6: Vendors providing a positive financial performance bear less risk to harm the reputation of the outsourcer, therefore capital markets react positively towards deal announcements including service providers having a high RoE.

\section{Methodology, Sample Design and Data}

\subsection{Methodology and Sample Design}

The event study methodology applied in this paper relies on the market model based approach suggested by (Fama, et al. 1969), perpetuated by (Brown and Warner 1980; Brown and Warner 1985; Cable and Holland 1999; MacKinlay 1997) and used by (Beitel, et al. 2004). Generally, event studies measure the capital market reaction (abnormal returns) of a certain stock after company-specific news has been issued towards investors. Cumulated abnormal returns are measured as difference between realized and expected returns over a certain time-period.

We extracted all financial services outsourcing deals from a comprehensive literature research, several general outsourcing databases and a comprehensive investigation of global financial newspapers for outsourcing deals. The search was conducted within the news database LexisNexis. A variety of search strings and keyword such as "outsourcing and financial services" has been scrutinized. This way we derived a unique database of financial 
services outsourcing deals covering a timeframe from January 1998 to March 2004 including a total of 272 deals in the global financial services industry with a deal volume larger than USD 10 million. To verify and complement relevant fundamental information for these 272 deals (e.g. the specific event date) we extracted and evaluated the official first press announcement regarding the signing of the specific outsourcing contract. Of these 272 transactions no precise event date could be identified for 76 deals, for additional 34 deals the involved companies are not publicly listed (e.g. smaller private banks) so that no relevant financial data could be extracted. Thus, our final cleaned and verified data set includes 182 outsourcing transactions in the global financial services industry within the timeframe from January 1998 to March 2004 and each transaction being larger than USD 10 million.

For 120 deals we were able to verify the fundamental information for both parties, i.e. outsourcer and insourcer. For additional 18 transactions, reliable data could be only retrieved for the outsourcer, for 44 cases only for the insourcer. Thus, the following sections relate to either 138 outsourcers, 164 insourcers or, if both parties of the transaction are known, to 120 combined entities.

\subsection{Data}

Table 2 provides an overview on the analyzed deals and their classification in business functionality and industry segment. Over the analyzed timeframe 1998 to March 2004, ITI was the largest area of outsourcing (72 deals, total deal volume USD 49.871 million), followed by BPO (61 deals, USD 39.934 million), ADM (30 deals, USD 19.899 million), and APO (7 deals, USD 10.600 million).

The most active outsourcer in terms of numbers of transactions has engaged in eight transactions, two financial services companies have engaged in five transactions, the remaining firms have engaged in four or less transactions during the timeframe in scope.

The most active insourcer in terms of numbers of transactions has engaged in 36 transactions; the top five most active service providers count for a total of 88 deals.

The service providers in scope or our analysis are, on average, more profitable than outsourcers (Return-on-Equity of 16.5 per cent vs. 13.4 per cent). The average market-tobook-ratio (MTB) is 2.70 for outsourcers and 4.77 for service providers. As outsourcers stem from the financial services industry and the vast majority of insourcers stems from the service providing industry, the different performance figures need careful interpretation.

\subsection{Analyzed variables}

We have analyzed a variety of explanatory variables to evaluate explanatory power with regard to capital market success of outsourcing announcements. Table 4 in the appendix provides an overview on the independent variables. Missing values have been estimated via OLS-regression. Values have been windsorized at 10 and 90 per cent level in order to account for outliers. The following section describes how we measure the drivers of capital market success.

\section{Results}

\subsection{Event Study Results}

Cumulative abnormal returns for outsourcers, insourcers and combined entities are presented in Table 5 in the appendix. Shareholders earn, on average, slightly negative (but mainly no significant) returns in most of the analyzed event windows. For the outsourcers we detect negative CARs in four of the analyzed five event windows. For the event window [-1;1] we 
detect a significant negative CAR of -0.50 per cent. For the insourcers, we detect negative CARs in four of the analyzed five event windows. The combined entities display a significant negative return of -1.62 per cent for the event window $[-10 ; 10]$ and a significant negative return of -2.17 per cent for the event window [-20;20].

These results slightly differ from previous related findings which mainly report positive cumulated abnormal returns. But readers should keep in mind that we focus on one industry (the financial services sector) and included not only IT-related sourcing announcements. Thus, our results are not really comparable to results from other studies focusing on various industries or cover only IT outsourcing (Albright 2003; Glassman 2000; Hunton, et al. 2000).

\subsection{Regression Results}

To analyze effects of several independent variables at the same time, we employ crosssectional multivariate regressions. We analyze CARs for the event window [-3;3] of outsourcers and insourcers. An overview of the results is provided in Table 6 in the appendix. For the separate analysis of outsourcers and insourcers a fixed-effects model has been employed since companies engage in several sourcing transactions during the observation period. The number of observations $(\mathrm{N})$ is lower than the total number of observations due to missing data. Missing data for independent variables has been estimated using OLSregression. Variables have been windsorized at 10 and 90 per cent level. Robustness checks for the other event windows have been performed indicating that our findings are robust.

\subsection{Evidence Regarding Outsourcers and Insourcers}

Table 6 columns 2, 3 and 4 provide a summary of the results for the outsourcers. The overall model is significant, based on an F-test $(\mathrm{p}<0.1)$ and explains about 52 per cent of the variance, which is acceptable for an exploratory research and a limited number or independent variables (Loh and Venkatraman 1992). Table 6 columns 4, 5 and 6 provide a summary of the results for the insourcers. The overall model is significant, based on an F-test $(\mathrm{p}<0.05) . \mathrm{R}^{2}$ is 0.31 .

Hypothesis 1 suggests that investors do not value large deals since they provide a higher level of sourcing risk. Our results provide support for the hypothesis. Outsourcer CARs show a significant negative relationship with deal size (coefficient sizeln). Thus, it can be concluded that large outsourcing transactions do not result in positive abnormal returns to shareholders. The coefficient on relative deal size (relsizeos), on the other hand, is positive and highly significant. This finding somehow contradicts the finding above. A financial services company that engages in a relative large transaction compared to its market capitalization is positively rewarded by capital markets. This finding might be explained with the assumption that transferring larger parts of the organization to a specialized service provider is potentially less risky and easier in terms of process cuts, interfaces and complexity to manage and control than transferring relative small heterogeneous organizational processes. For Service providers, on the other hand, we do not find a significant interrelationship, although the coefficient on sizeln is negative.

According to Hypothesis 2 we expected long deals to bear increased risks. Our results do not provide significant evidence to support this hypothesis. The coefficient on length is negative for the outsourcers and positive for the insourcers, though not significant.

In Hypothesis 3 we formulated the expectation that multi-vendor relationships (i.e. deals including an additional vendor or sub-contractor) provide potential for increased risks. Our results do not provide significant support for this hypothesis. Outsourcers including an additional vendor into the transaction do not significantly suffer from this constellation. 
According to our expectations the coefficient on addvend is negative but insignificant for the analyzed outsourcers. For service providers the coefficient is positive and insignificant.

According to Hypothesis 4 we expected capital markets to react positively towards deal announcements including experienced service providers. Our results do not provide significant support for this hypothesis; the coefficient on activeis is positive and insignificant. Hypothesis 5 suggests that sourcing of non-core activities (i.e. traditional IT-related services (ITI and ADM)) provide less risk potential compared to sourcing of core business activities such as APO or BPO. Surprisingly, our results show that financial services companies significantly benefit from BPO (the coefficient on $B P O$ is positive and significant). For outsourcers, capital markets significantly approve of outsourcing of business processes. Under the assumption that outsourcing of "traditional" IT related functions does not provide a competitive advantage or the chance to differentiate services investors might be convinced that sourcing of business functions enables financial services firms to provide superior products or services to their clients and thus the chance to improve the competitive position by differentiation. Under this assumption, results become explicable.

For the insourcers, on the other hand, we find positive and significant coefficients for nonBPO outsourcing, i.e. $A P O, A D M$, and ITI). Provision of non-core services which are scalable, standardized (or at least standardizable), homogeneous such as the functions APO, $\mathrm{ADM}$ and ITI and which are less complex to integrate compared to typical finance business processes is highly rewarded by investors on capital markets.

In Hypothesis 6 we formulated that financially successful service providers account for less risk. Our empirical findings do not provide significant support for this hypothesis. We expected that partnering with high-performing service-providing companies are positively rewarded by capital markets. Coefficients for Market-to-Book ratio (mtbis) are positive and Return-on-Equity (roeis) are negative, thus indicating ambiguity and no clear support.

Another interesting finding relates to the experience of the capital market regarding outsourcing activities (expmasens). We put all transactions in scope of our analysis in chronological order. The coefficient for this variable is negative (though very small) and significant. Obviously there is a negative relationship between cumulated abnormal returns and current outsourcing announcements. This finding can be attributed to the fact that investors over time get more cautious and are more knowledgeable about potential risks and drawbacks inherent in sourcing activities. Thus they are less prone towards sourcing activities compared to the "hype"-phase at the end of the 1990s. The following table summarizes our findings with regard to the respective hypothesis.

\begin{tabular}{|l|l|l|}
\hline Hypothesis & Finding & Interpretation \\
\hline $\begin{array}{l}\text { 1. Due to higher perceived risk of } \\
\text { financial miscalculations and general } \\
\text { financial risks of large projects, } \\
\text { investors are expected to react } \\
\text { negatively towards larger sourcing } \\
\text { announcements. }\end{array}$ & $\begin{array}{l}\text { Outsourcer CARs show a significant } \\
\text { negative relationship with deal size } \\
\text { (sizeln). For Service providers we do } \\
\text { not find a significant interrelationship, } \\
\text { although the coefficient on sizeln is } \\
\text { negative. On the other hand, the } \\
\text { coefficient on relative deal size } \\
\text { (relsizeos) is positive and highly } \\
\text { significant for the outsourcers. }\end{array}$ & $\begin{array}{l}\text { Measured as absolute size of the } \\
\text { transaction (sizeln), large outsourcing } \\
\text { transactions do not result in positive } \\
\text { abnormal returns to shareholders of the } \\
\text { outsourcer. On the other hand, the } \\
\text { (relsizeos) is positive and highly } \\
\text { significant. A financial services } \\
\text { company that engages in a relative } \\
\text { large transaction compared to its } \\
\text { market capitalization is positively } \\
\text { rewarded by capital markets. This } \\
\text { finding might be explained with the } \\
\text { assumption that transferring relative } \\
\text { large parts of the organization to a } \\
\text { specialized service provider is } \\
\text { potentially less risky and easier in } \\
\text { terms of process cuts, interfaces and }\end{array}$ \\
\hline
\end{tabular}




\begin{tabular}{|c|c|c|}
\hline & & \begin{tabular}{l}
\multicolumn{2}{l}{ complexity to manage and control than } \\
transferring \\
$\begin{array}{l}\text { heterogeneous } \\
\text { processes. }\end{array}$ \\
\end{tabular} \\
\hline $\begin{array}{l}\text { 2. Long running contracts inherent a } \\
\text { higher level of perceived financial risk, } \\
\text { as possible negative turn outs in the } \\
\text { future are costly to be corrected. Thus, } \\
\text { we expect investors to react negatively } \\
\text { towards outsourcing contracts having a } \\
\text { long duration. }\end{array}$ & $\begin{array}{l}\text { The coefficient on length is negative } \\
\text { for the outsourcers and positive for the } \\
\text { insourcers, though not significant. }\end{array}$ & $\begin{array}{l}\text { Our results do not provide significant } \\
\text { evidence to support this hypothesis }\end{array}$ \\
\hline $\begin{array}{l}\text { 3. Multiple service providers increase } \\
\text { complexity, thus the risk not to deliver } \\
\text { the required performance. Therefore } \\
\text { we expect capital markets to react } \\
\text { negatively towards deals including } \\
\text { multi-vendor relationships. }\end{array}$ & $\begin{array}{l}\text { The coefficient on addvend is negative } \\
\text { but insignificant for the analyzed } \\
\text { outsourcers. Outsourcers including an } \\
\text { additional vendor into the transaction } \\
\text { do not significantly suffer from this } \\
\text { constellation. For service providers the } \\
\text { coefficient is positive and } \\
\text { insignificant. }\end{array}$ & $\begin{array}{l}\text { Our results do not provide significant } \\
\text { support for this hypothesis. }\end{array}$ \\
\hline $\begin{array}{l}\text { 4. Experienced service providers have } \\
\text { a higher reputation in the market; } \\
\text { therefore investors react positively } \\
\text { towards deal announcements including } \\
\text { experienced vendors. }\end{array}$ & $\begin{array}{l}\text { The coefficient on activeis is positive } \\
\text { and insignificant. }\end{array}$ & $\begin{array}{l}\text { Our results do not provide significant } \\
\text { support for this hypothesis. }\end{array}$ \\
\hline $\begin{array}{l}\text { 5. We expect sourcing of activities } \\
\text { such as ITI and ADM to be rewarded } \\
\text { by capital markets while outsourcing } \\
\text { announcements with a high degree of } \\
\text { perceived privacy risk (such as APO or } \\
\text { BPO) will not be approved by capital } \\
\text { markets. }\end{array}$ & $\begin{array}{l}\text { The coefficient on } B P O \text { is positive and } \\
\text { significant for the outsourcers. } \\
\text { For insourcers we find positive and } \\
\text { significant coefficients for non-BPO } \\
\text { outsourcing (i.e. APO, ADM, and ITI). }\end{array}$ & $\begin{array}{l}\text { Our results show that financial services } \\
\text { companies significantly benefit from } \\
\text { BPO. Under the assumption that } \\
\text { outsourcing of "traditional" IT related } \\
\text { functions does not provide a } \\
\text { competitive advantage or the chance to } \\
\text { differentiate services investors might } \\
\text { be convinced that sourcing of business } \\
\text { functions enables financial services } \\
\text { firms to provide superior products or } \\
\text { services to their clients and thus the } \\
\text { chance to improve the competitive } \\
\text { position by differentiation. Under this } \\
\text { assumption, results become explicable. } \\
\text { For the insourcers, provision of non- } \\
\text { core services which are scalable, } \\
\text { standardized (or at least } \\
\text { standardizable), homogeneous such as } \\
\text { the functions APO, ADM and ITI is } \\
\text { highly rewarded by investors on } \\
\text { capital markets. }\end{array}$ \\
\hline $\begin{array}{l}\text { 6. Vendors providing a positive } \\
\text { financial performance bear less risk to } \\
\text { harm the reputation of the outsourcer, } \\
\text { therefore capital markets react } \\
\text { positively to outsourcers that include } \\
\text { service providers that have a high RoE. }\end{array}$ & $\begin{array}{l}\text { Coefficients for Market-to-Book ratio } \\
\text { (mtbis) are positive and Return-on- } \\
\text { Equity (roeis) are negative, thus } \\
\text { indicating ambiguity and no clear } \\
\text { support. }\end{array}$ & $\begin{array}{l}\text { Ambiguous. Our results do not provide } \\
\text { clear significant support for this } \\
\text { hypothesis. }\end{array}$ \\
\hline
\end{tabular}

Table 2: Overview of empirical results

\section{Conclusion}

This study provides a contribution to the actual scientific discussion in three ways. First, we contribute a link between perceived risk, outsourcing, and investor behavior on capital markets. Second, we broaden the scope of not only analyzing outsourcing of IT-related functionalities by evaluating outsourcing of business functionalities. And third, we narrow 
the focus of the analysis to one specific industry, the global financial services industry, which, in itself has a specific risk-avoiding attitude, instead of scrutinizing various heterogeneous industries. The performance differences of the analyzed deals show that investors do not have a principal (either positive or negative) general attitude towards sourcing in the financial services industry. Overall, our results indicate that capital markets on average do not show strong reactions towards new sourcing announcements. However, undertaking a cross-sectional regression analysis, we find strong and significant differences in investors' reactions towards the individual announcement.

This lead us to explore individual deal characteristics being either value creating, value destroying, or value neutral. Our results suggest that certain types of sourcing activities and specific transaction characteristics indeed do have a significant, positive influence on stockholder performance. These findings are consistent with the concept of perceived risk, as it shows that investors react accordingly in specific cases. Therefore the impact of the perceived risk on the investment decision needs to be assessed on a single case basis.

In summary it has shown that, although we argued that outsourcers can reap benefits of cost control, flexibility and increased efficiency, our overall results show that capital markets do not generally follow this view. Other deal characteristics may negatively outweigh the postulated upside potentials, leading to a careful reaction of investors. On the other hand, a variety of deals have received approval of capital markets. Managers of outsourcers thus need to eliminate downside characteristics of sourcing transactions and communicate potentials of cost-cutting, increased flexibility and efficiency. Getting more experienced and more knowledgeable about sourcing management and how to effectively shaping in-house processes, managers of financial services firms will be in a position to better monitor and control outsourced operations. Financial services companies will continue to make largescale outsourcing decisions. We find strong support in the market-place for this argument, where we observe more frequent and larger outsourcing contracts than five or ten years ago. Gaining experience and additional understanding of how investors perceive specific transaction characteristics, managers of financial services companies need to continue to adept and shape deals accordingly.

Insourcers, on the other hand, are already harvesting benefits from additional transactions. Because of anticipated positive reactions of capital markets, vendors will increasingly compete for large-scale insourcing projects. Again, we find that strong support for this argument in the market-place. 


\section{Appendix}

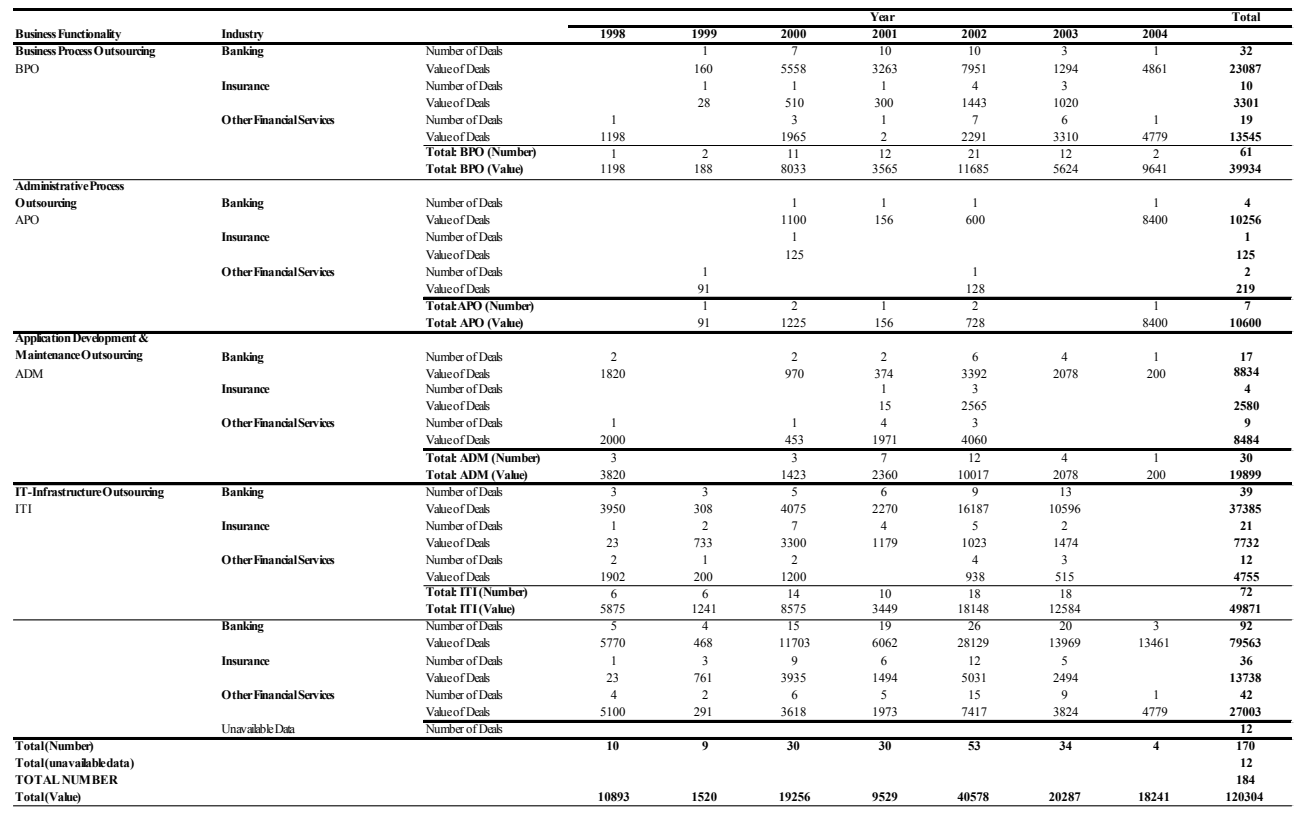

Table 3: Number and value of deals according to respective business functionality and industry classification. ( $\mathrm{N}=170 ; 12$ transactions have been omitted in this table since relevant data could not be extracted). The industry classification of the outsourcing company has been taken according to the classification in Bloomberg. For missing deal values OLS regression has been performed.

\begin{tabular}{|c|c|c|c|c|c|c|}
\hline Variable & Description & Obs. & Mean & Std.-Dev. & Min & Max \\
\hline \multicolumn{7}{|l|}{ Deal Characteristics } \\
\hline size & Transaction Volume & 170 & 523.17 & 437.60 & 71.18 & 1450.00 \\
\hline sizeln & $L N$ of Transaction Volume & 170 & 5.85 & 0.98 & 4.27 & 7.28 \\
\hline length & Deal Duration & 182 & 7.58 & 1.78 & 5.00 & 10.00 \\
\hline lengthln & LN of Deal Duration & 182 & 2.00 & 0.24 & 1.61 & 2.30 \\
\hline mposis & Market Cap OS /Market Cap IS & 176 & 3.12 & 4.95 & 0.03 & 15.11 \\
\hline mposisln & LN (Market Cap OS / Market Cap IS) & 176 & -0.43 & 2.00 & -3.47 & 2.72 \\
\hline expmasens & Experience of Market & 182 & 91.50 & 49.78 & 19.00 & 164.00 \\
\hline banking & Functionality: Banking & 92 & & & 0.00 & 1.00 \\
\hline insurance & Functionality: Insurance & 36 & & & 0.00 & 1.00 \\
\hline fs & Functionality: Other Financial Services & 42 & & & 0.00 & 1.00 \\
\hline bpo & Business Process Outsourcing & 63 & & & 0.00 & 1.00 \\
\hline apo & Administrative Process Outsourcing & 7 & & & 0.00 & 1.00 \\
\hline adm & Application Development \& Maintenance & 39 & & & 0.00 & 1.00 \\
\hline iti & IT-Infrastructure Outsourcing & 73 & & & 0.00 & 1.00 \\
\hline european & Region: Europe & 71 & & & 0.00 & 1.00 \\
\hline northamerica & Region: Northamerica & 58 & & & 0.00 & 1.00 \\
\hline apac & Regaion: AsialPacific & 21 & & & 0.00 & 1.00 \\
\hline africamidd & Region: Africa \& Middle East & 1 & & & 0.00 & 1.00 \\
\hline global & Region: Global & 10 & & & 0.00 & 1.00 \\
\hline addvend & Additional Vendor Included & 7 & & & 0.00 & 1.00 \\
\hline y98 & 1998 & 10 & & & 0.00 & 1.00 \\
\hline y 99 & 1999 & 13 & & & 0.00 & 1.00 \\
\hline y00 & 2000 & 30 & & & 0.00 & 1.00 \\
\hline y01 & 2001 & 32 & & & 0.00 & 1.00 \\
\hline y02 & 2002 & 55 & & & 0.00 & 1.00 \\
\hline $\mathrm{y} 03$ & 2003 & 38 & & & 0.00 & 1.00 \\
\hline y04 & 2004 & 4 & & & 0.00 & 1.00 \\
\hline \multicolumn{7}{|c|}{ Outsourcer Characteristics } \\
\hline mcapos & Market Capitalization of OS & 181 & 27363.95 & 32995.22 & 25.83 & 236607.00 \\
\hline mposln & LN of Market Cap of OS & 181 & 9.47 & 1.25 & 7.30 & 10.94 \\
\hline relsizos & Transaction Volume / Market Cap of OS & 170 & 0.29 & 1.25 & -0.03 & 9.68 \\
\hline relsizosln & LN (Transaction Volume / Market Cap of OS) & 169 & -3.64 & 1.55 & -6.05 & -1.09 \\
\hline roeos & Return-on-Equity of OS & 182 & 0.1396 & 0.0655 & 0.0333 & 0.2366 \\
\hline mtbos & Market-to-Book Ratio of OS & 182 & 2.47 & 1.20 & 1.12 & 4.91 \\
\hline expos1 & First Deal of OS & 124 & & & 0.00 & 1.00 \\
\hline expos2 & Second Deal of OS & 28 & & & 0.00 & 1.00 \\
\hline exposmore2 & More than second deal of $O S$ & 30 & & & 0.00 & 1.00 \\
\hline \multicolumn{7}{|c|}{ Insourcer Characteristics } \\
\hline mcapis & Market Capitalization of IS & 177 & 51899.54 & 67686.72 & 6.85 & 230206.60 \\
\hline mpisln & LN of Market Cap of IS & 177 & 9.84 & 1.55 & 7.40 & 12.13 \\
\hline relsizos & Transaction Volume / Market Cap of IS & 165 & 0.18 & 0.83 & 0.00 & 6.71 \\
\hline relsizisln & LN (Transaction Volume / Market Cap of IS) & 165 & -4.03 & 1.50 & -6.34 & -1.85 \\
\hline roeis & Return-on-Equity of IS & 182 & 0.1777 & 0.1076 & 0.0100 & 0.3517 \\
\hline mtbis & Market-to-Book Ratio of IS & 182 & 4.46 & 2.59 & 1.30 & 9.12 \\
\hline activeis & Active IS (more than 25 deals) & 61 & & & 0.00 & 1.00 \\
\hline
\end{tabular}

Table 4: Independent variables. Data for performance figures has been extracted from Datastream and Bankscope. Data for RoE, and C/IRatio has been taken on year-end of the year prior to the announcement date. Data for MtB and P/E-Ratio hast been taken on t=-21 (i.e. 21 
days prior to the announcement). Data for missing values has been estimated via OLS regression. Variables have been windsorized at 10 / 90 per cent level in order to correct for outlying values.

\begin{tabular}{|c|c|c|c|c|c|c|c|c|}
\hline Event Window & Obs. & CAR in \% & & Std.Dev. & Min & Max & Pos. & Neg. \\
\hline \multicolumn{9}{|l|}{ Outsourcer } \\
\hline$\{0\}$ & 138 & $0.02 \%$ & & $1.52 \%$ & $-2.25 \%$ & $2.33 \%$ & 69 & 69 \\
\hline$[-1 ; 1]$ & 138 & $-0.50 \%$ & $* *$ & $2.38 \%$ & $-4.29 \%$ & $3.33 \%$ & 63 & 75 \\
\hline$[-3 ; 3]$ & 138 & $-0.18 \%$ & & $3.59 \%$ & $-5.93 \%$ & $5.80 \%$ & 65 & 73 \\
\hline$[-10 ; 10]$ & 138 & $-0.56 \%$ & & $5.41 \%$ & $-9.55 \%$ & $7.68 \%$ & 63 & 75 \\
\hline$[-20 ; 20]$ & 138 & $-0.43 \%$ & & $7.24 \%$ & $-11.82 \%$ & $10.62 \%$ & 67 & 71 \\
\hline \multicolumn{9}{|l|}{ Insourcer } \\
\hline$\{0\}$ & 164 & $-0.14 \%$ & & $1.68 \%$ & $-2.89 \%$ & $2.61 \%$ & 82 & 82 \\
\hline$[-1 ; 1]$ & 164 & $-0.12 \%$ & & $2.65 \%$ & $-4.90 \%$ & $3.77 \%$ & 83 & 81 \\
\hline$[-3 ; 3]$ & 164 & $0.35 \%$ & & $4.38 \%$ & $-7.05 \%$ & $6.95 \%$ & 83 & 81 \\
\hline$[-10 ; 10]$ & 164 & $-0.45 \%$ & & $8.40 \%$ & $-13.14 \%$ & $13.22 \%$ & 76 & 88 \\
\hline$[-20 ; 20]$ & 164 & $-1.45 \%$ & & $13.39 \%$ & $-21.82 \%$ & $20.82 \%$ & 70 & 94 \\
\hline \multicolumn{9}{|l|}{ Combined Entity } \\
\hline$\{0\}$ & 120 & $0.06 \%$ & & $1.26 \%$ & $-1.89 \%$ & $1.99 \%$ & 67 & 53 \\
\hline$[-1 ; 1]$ & 120 & $-0.07 \%$ & & $2.18 \%$ & $-3.74 \%$ & $3.04 \%$ & 64 & 56 \\
\hline$[-3 ; 3]$ & 120 & $0.03 \%$ & & $3.18 \%$ & $-4.60 \%$ & $5.33 \%$ & 56 & 64 \\
\hline$[-10 ; 10]$ & 120 & $-1.62 \%$ & $* * *$ & $5.73 \%$ & $-11.15 \%$ & $6.61 \%$ & 51 & 69 \\
\hline$[-20 ; 20]$ & 120 & $-2.17 \%$ & $* * *$ & $8.47 \%$ & $-15.90 \%$ & $12.60 \%$ & 47 & 73 \\
\hline
\end{tabular}

Table 5: Results of the event study analyzing outsourcing transactions in the global financial services industry covering the timeframe from 1998 to March 2004. Abnormal returns have been calculated using OLS-regression. OLS-parameters have been estimated for a period of 252 trading days (1 trading year) prior to the event window [-20;20]. As market returns we have used the relevant industry indices S\&P 500, MSCI World Banks, MSCI World Insurance and MSCI World Financial Services as provided by DataStream and Bloomberg. Cumulated abnormal returns (CARs) have been windsorized at 10 and 90 per cent level. $* * * * * / *$ indicate significance at the $1 / 5 / 10$ per cent level

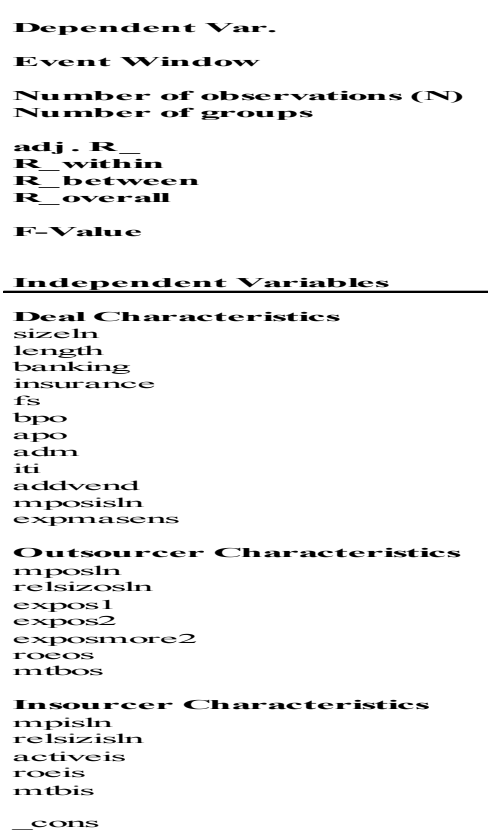

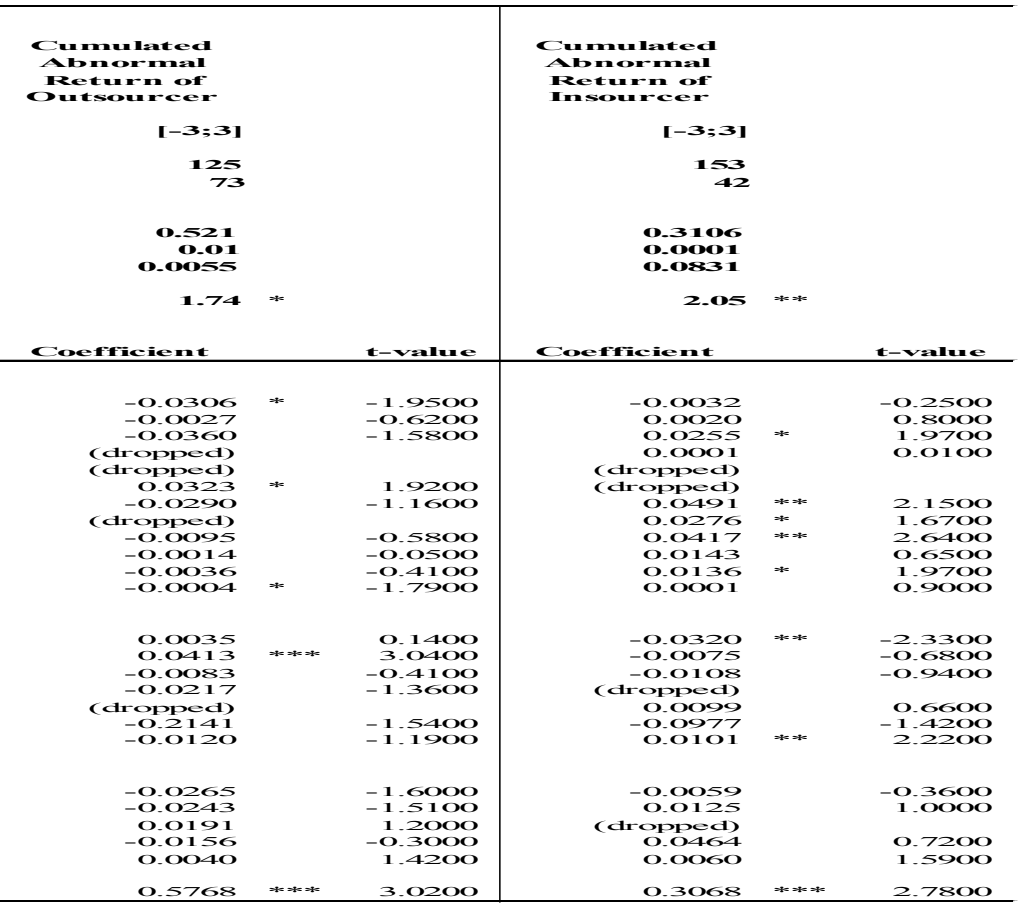

Table 6: Results of the multivariate cross sectional OLS-regression for the cumulated abnormal returns of outsourcers, insourcers and combined entity. Dependent variable is cumulated abnormal return for the event window [-3;3]. For the separate analysis of outsourcers and insourcers a fixed-effects model has been employed. The number of observations $(\mathrm{N})$ is lower than the total number of observations due to missing data. Missing data for independent variables has been estimated using OLS-regression. Variables have been windsorized at 10 and 90 per cent level. Logarithms (ln) has been used for the variables size, market capitalization of outsourcer and insourcer, relative size of the parties and relative deal size compared to the market capitalization. Robustness checks for the other event windows have been performed 
and results are robust. Relevant data regarding the independent variables has been extracted from Bankscope, Datastream or the original deal announcement. $* * * / * * / *$ indicate significance at the $1 / 5 / 10$ per cent level.

\section{8. $\quad$ References}

Albright, C. "Outsourcing for outsized gains," Marakon Associates Research, 2003.

Aubert, B.A., Patry, M., and Rivard, S. "Assessing the risk of IT outsourcing," Proceedings of the 31st Hawaii International Conference on System Sciences, 1998.

Bain, J. "Economies of scale, concentration and entry," American Economic Review (44), 1954, pp. 15-39.

Bauer, R. "Consumer Behavior as Risk Taking," In Risk Taking and Information Handling in Consumer Behavior, D. F. Cox (ed.) Harvard University Press, Cambridge, MA, USA, 1967, pp. 21-33.

Beitel, P., Schiereck, D., and Wahrenburg, M. "Explaining the M\&A-success in European bank mergers and acquisitions," European Financial Management (10:1), 2004, pp. 109-132.

Benamati, J.H., and Rajkumar, T.M. "An Empirical Study of the Applicability of the Technology Acceptance Model to Application Development Outsourcing Decisions," Proceedings of the 9th Americas Conference on Information Systems, Tampa, FL, USA, 2003.

BIS "International Convergence of Capital Measures and Capital Standards," Bank for International Settlements, Basel Committee on Banking Supervision, 2004.

Brown, S., and Warner, J. "Measuring security price performance," Journal of Financial Economics (8), 1980, pp. 2-23.

Brown, S., and Warner, J. "Using daily stock returns: The case of event studies," Journal of Financial Economics (14), 1985, pp. 3-31.

Cable, J., and Holland, K. "Modeling normal returns in event studies: a model-selection approach and pilot study," The European Journal of Finance (5), 1999, pp. 331 - 341.

Caldwell, B.M. "IT Outsourcing Contracts: Crunching the Numbers," Gartner Dataquest Research Brief, 2003.

Cox, D.F. "Risk Handling in Consumer Behavior," In Risk Taking and Information Handling in Consumer Behavior, D. F. Cox (ed.) Harvard University Press, Boston, MA, USA, 1967, pp. 3481.

Cunningham, S.M. "The Major Dimensions of Perceived Risk," In Risk Taking and Information Handling in Consumer Behaviour, D. F. Cox (ed.) Harvard University Press, Boston, MA, USA, 1967, pp. 82-108.

Currie, W.L. "Using multiple suppliers to mitigate the risk of IT outsourcing at ICI and Wessex Water," Journal of Information Technology (13), 1998, pp. 169 - 180.

Dibbern, J., Goles, T., Hirschheim, R., and Jayatilaka, B. "Information systems outsourcing: A survey and analysis of the literature," The DATA BASE for Advances in Information Systems (35:4), 2004, pp. 6-102.

Earl, M.J. "The risks of outsourcing IT," Sloan Management Review (37:3), 1996, pp. 26-32.

Fama, E.F., Fisher, L., Jensen, M.C., and Roll, R. "The adjustment of stock prices to new information," International Economic Review (10), 1969, pp. 1-21.

Farag, N.I., and Krishnan, M.S. "The market value of IT outsourcing investment announcements: An event-study analysis," Proceedings of the Ninth Americas Conference on Information Systems, 2003.

Featherman, M.S., and Pavlou, P.A. "Predicting e-Services Adoption: A Perceived Risk Facets Perspective," International Journal of Human-Computer Studies (59), 2003, pp. 451-474.

Featherman, M.S., and Wells, J.D. "The Intangibility of E-Services: Effects on Artificiality, Perceived Risk, and Adoption," Proceedings of the 37th Hawaii International Conference on System Sciences, Hawaii, 2004.

Friedrich, L., and Gellrich, T. "Capital market reaction to financial services outsourcing," E-Finance Lab Working Paper, 2003.

Gallivan, M.J., and Oh, W. "Analyzing IT outsourcing relationships as alliances among multiple clients and vendors," Proceedings of the 32nd Hawaii International Conference on System Sciences, Hawaii, 1999. 
Gewald, H., and Franke, J. "A Comparison of the Risks in Information Technology Outsourcing and Business Process Outsourcing," Proceedings of the 11th Americas Conference on Information Systems, Omaha, NE, USA, 2005.

Gewald, H., and Hinz, D. "A Framework for Classifying the Operational Risks of Outsourcing," Proceedings of the 8th Pacific Asia Conference on Information Systems, Shanghai, PR China, 2004.

Glassman, D. "IT outsourcing and shareholder value," Stern Stewart Research - EVAluation, 2000.

Grover, V., Cheon, M.J., and Teng, J.T.C. "The effect of service quality and partnership on the outsourcing of IS functions," Journal of Management Information Systems (12:4), 1996, pp. 89116.

Huber, R. "How continental bank outsourced its crown jewels," Harvard Business Review (71:January / February), 1993, pp. 121-129.

Hunton, J., Reck, J., and Hayes, D. "The market's reaction to information systems outsourcing announcements," Journal of Information Systems (14:2), 2000, pp. 109-125.

Jensen, M.C., and Meckling, W.H. "Theory of the firm: Managerial behaviour, agency costs and ownership structure," Journal of Financial Economics (3), 1976, pp. 305-360.

Kern, T., Willcocks, L.P., and Lacity, M.C. "Application service provision: Risk assessment and mitigation," MIS Quarterly Executive (1:2), 2002, pp. 113-126.

Lacity, M.C. "Lessons in global information technology," Computer (August), 2002, pp. 26-33.

Lacity, M.C., Willcocks, L.P., and Feeny, D.F. "The value of selective IT sourcing," Sloan Management Review (Spring), 1996, pp. 13-25.

Lassig, P., Lamberti, H.-J., and Jochum, C. "Scoring- und beiderseitige Due-Diligence-Prozesse im Rahmen der Lieferantenauswahl beim Infrastrukturoutsourcing," Wirtschaftsinformatik (45:2), 2003, pp. 147-156.

Loh, L., and Venkatraman, N. "Determinants of information technology outsourcing: A crosssectional analysis," Journal of Management Information Systems (9:1), 1992, pp. 7-24.

MacKinlay, A.C. "Event studies in economics and finance," Journal or Economic Literature (35:March 1997), 1997, pp. 13-39.

Michell, V., and Fitzgerald, G. "The IT outsourcing marketplace: vendors and their selection," Journal of Information Technology (12), 1997, pp. 223-237.

Mitchell, V.-W. "Understanding Consumer's Behaviour: Can Perceived Risk Theory Help?," Management Decision (30:3), 1992, pp. 26-31.

Oh, W., and Gallivan, M.J. "An empirical assessment of transaction risks of IT outsourcing arrangements: An event study," Proceedings of the 37th Hawaii International Conference on System Sciences, Hawaii, 2004.

Pavlou, P.A. "Consumer Acceptance of Electronic Commerce: Integrating Trust and Risk with the Technology Acceptance Model," International Journal of Electronic Commerce (7:3), 2003, pp. 69-103.

Peter, J.P., and Ryan, M.J. "An Investigation of Perceived Risk at the Brand Level," Journal of Marketing Research (13:May), 1976, pp. 184-188.

Prahalad, C.K., and Hamel, G. "The core competence of the corporation," Harvard Business Review (68:3), 1990, pp. 79-91.

Quinn, J.B., and Hilmer, F.G. "Strategic outsourcing," Sloan Management Review (35:4), 1994, pp. 43-55.

TPI "The TPI Index Q4/2005," www.tpi.net, 2005.

Venkatraman, N., and Loh, L. "The shifting logic of the IS organization: From technical portfolio to relationship portfolio," Information Strategy (10:2), 1994, pp. 5-11.

Willcocks, L.P., Lacity, M.C., and Kern, T. "Risk mitigation in IT outsourcing strategy revisited: longitudinal case research at LISA," Journal of Strategic Information Systems (8:3), 1999, pp. 285 314.

Young, P.C., and Hood, J. "Risk and the Outsourcing of Risk Management Services: The Case of Claims Management," Public Budgeting \& Finance (23:3), 2003, pp. 109-119. 